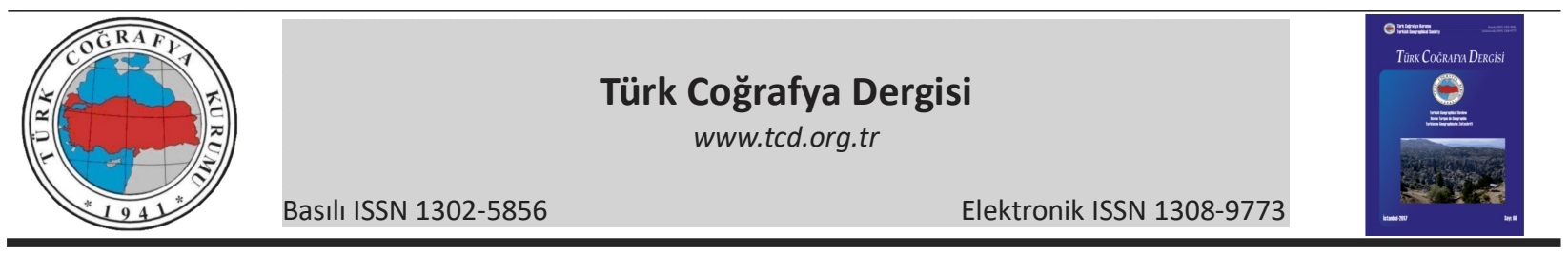

\title{
Dorutay Ovası ve yakın çevresindeki kırsal yerleşmelerin coğrafi özellikleri ${ }^{1}$
}

\author{
Geographical characteristics of rural settlements in Dorutay Plain and immediate surroundings
}

\author{
Murat Yılmaz*a \\ ${ }^{a}$ Yüzüncü Yıl Üniversitesi, Eğitim Fakültesi, Sosyal Bilimler ve Türkçe Bölümü, Van.
}

\section{MAKALE BILGi}

Geliş/Received: 19.10.2016

Kabul/Accepted: 20.01.2017

\section{Anahtar Kelimeler:}

Dorutay Ovası

Kırsal yerleşme

Nüfus

Göç

Yer adları

Keywords:

Dorutay Plain

Rural settlement

Population

Migration

Place names

*Sorumlu yazar/Corresponding author (M. Yılmaz) myilmazcog@yyu.edu.tr

http://dx.doi.org/10.17211/tcd.314753

\section{ÖZ / ABSTRACT}

Bu çalışmada Dorutay Ovası ve yakın çevresindeki kırsal yerleşmelerin coğrafi özelliklerinin incelenmesi amaçlanmıştı. Dorutay ovası ve yakın çevresi Van Ili'ne bağı Özalp, Saray ve Çaldıran ilçelerinin idari alanlarında yer almaktadır. Araştırma sahasında günümüzde 22'si köy 2'si mahalle olmak üzere toplam 24 kırsal yerleşme bulunmakta ve bu yerleşmelerde 29939 kişilik bir nüfus yaşamaktadır. Dorutay ovası ve çevresinde yer alan köy yerleşmeleri ova ve dağ-tepe eteklerinde yer almaktadır. Araştırma Sahasındaki köy yerleşmelerinin tamamı toplu dokuludur. Yükseltinin fazla olduğu sahada yerleşmenin alt ve üst sınırı da yüksek olup bu değerler sırasıyla 2000 ve 2250 m.ler dir. Araştırma sahasında ortalama köy idari alanı nüfus büyüklüğü 1360 iken köy nüfusları 252 ile 4773 arasında değişmektedir. İnceleme alanındaki köylerin eski ve yeni isimlerinin fiziki ve beşeri coğrafya unsurlarından izler taşıdığı görülmektedir. Araştırma sahasındaki köy yerleşmelerinde başlıca ekonomik faaliyet ziraat ve hayvancılıktır. Geçim kaynaklarının sınırlı olduğu yörede, dışarıya yönelik göçler devam etmektedir. Göçü azaltmak için tarım ve hayvancılığın daha verimli metotlarla yapılması ve yörede potansiyeli bulunan mandıracılık, arıcılık ve kültür balıkçılığı gibi alternatif geçim kaynaklarının geliştirilmesi gerekmektedir.

It is aimed in this study to examine the geographical characteristics of rural settlements in Dorutay plain and immediate surrounding which is located east part of Turkey. It is located in the administrative area of the Özalp, Saray and Çaldıran districts of Van Province. In the research area, currently, there are 24 rural settlements including 2 hamlets 22 villages and the population in these settlements are 29939. The geographical characteristics of settlements in the Dorutay plain and immediate surrounding vary from each other. The plain areas and foothills are selected as settlement places. In the research area, all the village settlements are collective textured. Altitude of the settlement in the area is high and so are the upper and lower limits which are respectively 2000 and 2250 meters. In the study area, average village population is 1360 and population of the villages vary between 252 and 4773. The old and the new names of the villages in research area have marks of the physical and human geography of the area. In the study area, main economic activities of villagers are agriculture and livestock. People from the region continue to migrate outwards because of limited livelihoods. Agriculture and livestock need to be done by more efficient methods to reduce migration from the region. Also, it is necessary to develop alternative livelihoods such as livestock, beekeeping and aquaculture which have potentials in the region.

${ }^{1}$ Bu çalışma 23-26 Mayıs 2016 tarihleri arasında Antalya Kemer'de yapılan 4. Uluslararası Coğrafya Sempozyumu'nda sözlü bildiri olarak sunulmuştur.

\section{Giriş}

Araştırma sahası Dorutay Ovası ve yakın çevresinden oluşmaktadır. İnceleme alanının kuzeybatısında bulunan Tekindere Köyü Çaldıran İlçesi'nin, güneydoğusunda bulunan Bakışık Köyü ise Saray İlçesi'nin idari alanında yer alırken sahanın geri kalan kısmı Özalp İlçesi'nin sınırları içinde kalmaktadır. Araştırma sahası kabaca Özalp İlçesi'nin kuzeydoğusunu oluşturmaktadır. İnceleme alanının doğusunda İran, kuzeyinde Çaldıran ilçesi, batısında ve güneyinde Özalp ilçesinin araştırma sahasında yer almayan kesimleri ile Saray ilçesi yer almaktadır (Şekil 1).

Araştırma sahası Van Gölü'ne dökülen Karasu nehri havzasının yukarı çı̆̆ırını oluşturmaktadır. Yükseltinin fazla olduğu sahada, karasal iklim görülmektedir. Araşttrma sahasında günümüz itibariyle 22 köy ve 2 mahalle olmak üzere 24 kırsal yerleşme bulunmakta ve bu yerleşmelerde 29939 (2015) kişi yaşamaktadır.

\section{Amaç ve Yöntem}

Çalışmanın temel amacı Dorutay ovası ve yakın çevresinde yer alan kırsal yerleşmeleri yükselti basamağı, nüfus büyüklüğü, konum, yerleşme dokusu, yer adları ve ekonomik faaliyetler gibi çeşitli coğrafi özelliklerine göre incelemektir. 


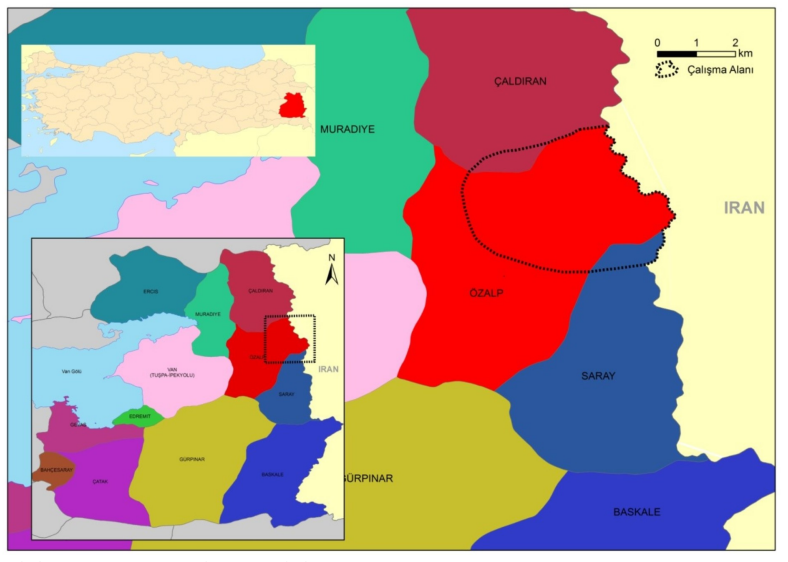

Şekil 1. Araştırma sahasının lokasyonu.

Figure 1. Location of study area.

Bu nedenle yörenin fiziki ve beşeri çevre özelliklerini daha iyi analiz etmek için haritalandırma, fotoğraflandırma, tablo ve grafikler yapma yoluna gidilmiştir. Yörenin fiziki coğrafya koşullarının ortaya konması için haritaların yanı sıra klimatik faktörlerin de analizi yapılmıştır.

Ayrıca sahada gözlem ve mülakat yoluyla kırsal hane halklarının göç ve ekonomik faaliyetlerle ilgili görüşleri ile fiziki-beşeri çevre şartlarından kaynaklanan sorunlar tespit edilmeye çalışılmıştr.

Araştırmada ayrıca yöredeki doğal artış hızı ile gerçek nüfus artış hızı arasındaki ilişki ele alınmış ve buna bağlı olarak yöreden dışarıya yönelik göçler hakkında bazı çıkarımlarda bulunulmuştur.

Çalışmada ilk olarak coğrafi çevre koşulları ele alınmış, daha sonra Cumhuriyet dönemindeki nüfus gelişimi üzerinde durulmuştur. İlerleyen bölümde kırsal yerleşmeler çeşitli coğrafi özelliklerine göre kategorize edilmiş ve çalışma sonuçlandırılmıştır.

\section{Bulgular}

\subsection{Coğrafi Çevre Koşulları}

Karasuyun yukarı çığırı boyunca birbirine ekli, üçgen şeklinde iki küçük ova gözükür. Bunlardan doğudakinin bir kısmına Tulgalı (Ahurik) en geniş kısmına Günyüzlü (Tarhani) düzü, Dorutay (Taşrumi) bucağı merkezinden aşağıda kalana da Sağmallı (Noşar) düzü denir. Bunlardan birincisinin yüz ölçümü 50 km²,

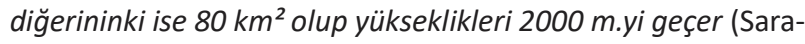
çoğlu, 1989).

Yukarıdaki örnekte de anlaşıldığı gibi eski kaynaklarda Dorutay ovasını oluşturan düzlüklerin farklı kesimleri için Tarhani, Noşar, Taşrumi gibi çeşitli isimler kullanılmaktaydı. Ancak bu çalışmada irili ufaklı bu düzlüklerin hepsi için Dorutay Ovası adı kullanılacaktır. Araştırma sahası Dorutay Ovası ile çevresindeki dağlık ve tepelik alanlardan oluşmaktadır. Dorutay Ovası'nda yükselti 2000-2150 m.ler arasında değişirken çevredeki dağlık alanlarda yükselti 2830 m.ye kadar çıkmaktadır. Nitekim sahanın güneyindeki tepelerde $2200 \mathrm{~m}$. civarında olan yükselti kuzeydeki Ziyaret Tepe'de 2685 m.ye çıkmaktadır. Yükselti doğudaki Hacımuhammet Tepe'sinde 2759 m.ye, batıdaki Hayal Dağı'nda 2827 m.ye çıkmaktadır. Yukarıdaki açıklamalardan da anlaşılacağı üzere Dorutay Ovası'nın alçak kesimlerinde 2000 m. civa- rında olan yükselti kısa mesafede oldukça fazla artmakta ve çevredeki volkanik dağ ve tepelerde 2750-2850 m. gibi yüksek değerlere çıkmaktadır (Saraçoğlu, 1989) (Şekil 2).

Dorutay Ovası (Fotoğraf 1) Van Gölü’ne dökülen Karasu Çayı'nın doğduğu yerdir. Kaynağını ovanın çevresindeki dağlık tepelik alanlardan alan Balçıklı, Oymaklı, Karataş, Dağdelen gibi çok sayıda dere, Dorutay Köyü yakınlarında birleşerek Karasu Çayı'nı oluşturmaktadır (Saraçoğlu, 1990) (Şekil 2). Karasu Çayı Dorutay Ovası'nda kabaca güneydoğu-kuzeybat istikametinde akarken ovanın batı sınırından itibaren kabaca kuzeydoğu-güneybatı istikametinde akmaktadır. Erçek Gölü’nün kuzeydoğusunda batiya yönelen akarsu Van Gölü'ne yakın konumda yer alan alüvyal birikinti alanında (Mermit çevresi) menderesler çizerek göle dökülür (Saraçoğlu, 1990) (Erinç, 1951). Karasu Çayı üzerinde Muradiye İlçesi'ne bağı Sarımehmet Köyü ile Özalp İlçesi'ne bağlı Şemsettin Köyleri arasında uzanan Sarımehmet Barajı yer alır. Sulama amaçlı bu barajın suları Karasu Çayı havzasının aşağı kesiminde yer alan arazileri sulamak için kullanılır.

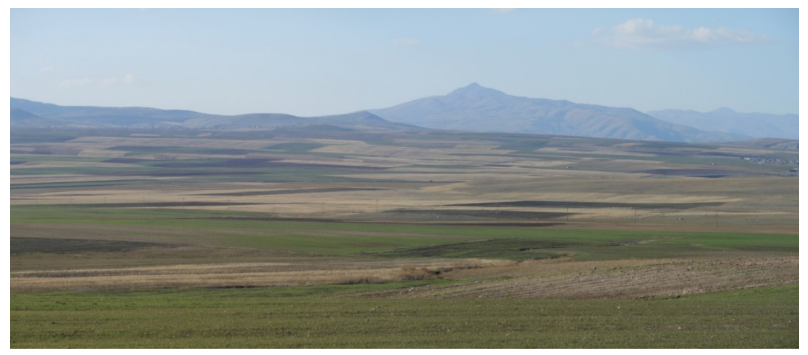

Fotoğraf 1. Dorutay Ovası'ndan bir görünüm.

Photo 1. A view from Dorutay plain.

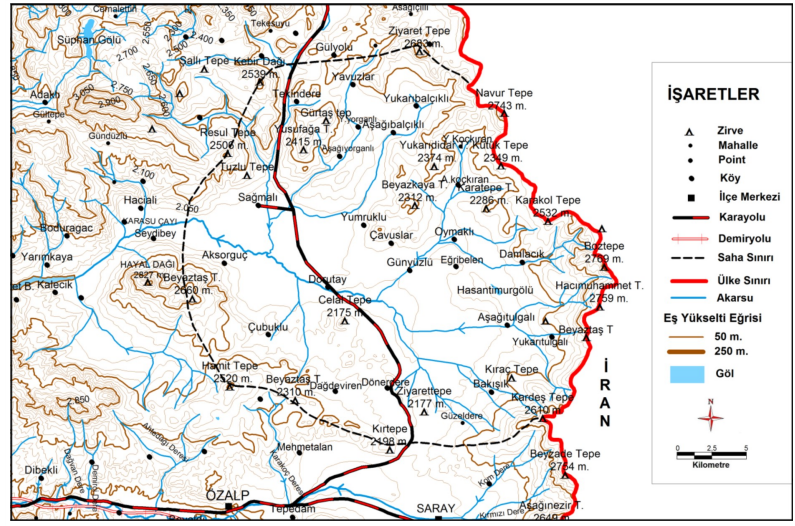

Şekil 2. Araştırma sahası ve yakın çevresinin topoğrafya haritası.

Figure 2. Topographic map of Dorutay plain and immediate surroundings.

Inceleme alanında meteoroloji istasyonu bulunmamaktadır. Bu nedenle yörenin iklimi hakkında fikir vermesi için Dorutay Ovası'na en yakın konumdaki Özalp Meteoroloji İstasyonu'nun verileri incelenmiştir. Özalp Meteoroloji İstasyonunun verilerine bakıldığı zaman, bu merkezde yıllık sıcaklık ortalamasının $6^{\circ} \mathrm{C}$, amplitüdün ise $30,5^{\circ} \mathrm{C}$ olduğu görülmektedir. Donlu gün sayısının yaklaşık olarak $175(174,7)$ olduğu Özalp'ta, Ocak ayı sıcaklık ortalaması $-9,6{ }^{\circ} \mathrm{C}$ dir (Tablo 1 ). Yörede Temmuz ayında başlayan ve Eylül ayı sonuna kadar devam eden yaklaşık 3 aylık dönemde kuraklık belirgindir.

Özalp meteoroloji istasyonunun verileri detaylı bir şekilde incelendiğinde yörede karasal termik rejim özelliklerinin etkili olduğu görülmektedir (Yılmaz, 2016a). Özalp’ta ölçülen 
değerlerin inceleme alanında bire bir aynı olduğu söylenemez. Ancak sahaya en yakın meteoroloji istasyonu olan Özalp'ın değerlerinin fikir vermesi açısında göz önüne alınması yararlı olacaktır. Dolayısıyla adı geçen istasyona yakın olan araştırma sahasında karasal iklim özelliklerinin görüldüğü söylenebilir.

Özalp'ta yaklaşık $500(498,8)$ mm. olan yıllık toplam yağış, aylar arasında dengeli bir şekilde dağılmamıştır. Adı geçen merkezde en yağışlı aylar sırasıyla Mayıs ve Nisan, yağışın en az olduğu aylar Eylül ve Ağustos'tur (Tablo 1, Şekil 3). Özalp'ta yağışın yıl içindeki dağılımı incelendiğinde bahar ve kış aylarında yağışın daha fazla olduğu, sonbahar ve yaz aylarında ise yağışın az olduğu görülmektedir. Özellikle Temmuz başından Eylül sonuna kadar olan 3 ay, yörede yağışın en az düştüğü dönemi oluşturmaktadır (Şekil 3).

Tablo 1. Özalp'ta sıcaklık ve yağışın aylara göre dağılımı (1975-2014).

Table 1. Temperature and precipitation changes by months in Özalp (between 1975-2014).

\begin{tabular}{lllllllllllllc}
\hline Aylar & $\mathrm{O}$ & S & $\mathrm{M}$ & $\mathrm{N}$ & $\mathrm{M}$ & $\mathrm{H}$ & $\mathrm{T}$ & $\mathrm{A}$ & $\mathrm{E}$ & $\mathrm{Ek}$ & $\mathrm{K}$ & $\mathrm{A}$ & Ylllık \\
\hline Ortalama Sıcaklık & $-9,6$ & $-8,3$ & $-2,3$ & 5,7 & 10,7 & 16,1 & 20,9 & 20,3 & 14,8 & 7,9 & 1,0 & $-5,8$ & 6,0 \\
Yağıș & 51,5 & 51,1 & 52,6 & 65,2 & 71,8 & 35,1 & 16,6 & 9,1 & 8,8 & 41,2 & 47,2 & 48,6 & 498,8 \\
Donlu Gün Say. & 31,0 & 28,2 & 28,9 & 15,7 & 2,7 & 0,2 & - & - & 0,6 & 12,3 & 24,7 & 30,4 & 174,7 \\
\hline \multicolumn{2}{l}{ Kaynak MGM veriler } & & & & & & & & & & & &
\end{tabular}

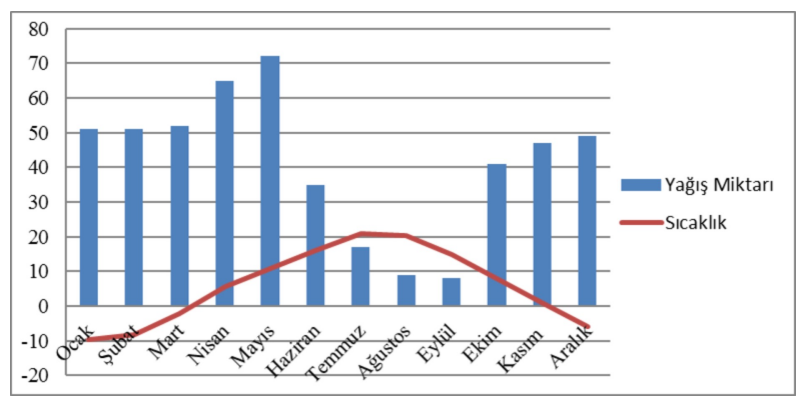

Şekil 3. Özalp'ta sıcaklık ve yağışın aylara göre dağılımı grafiği.

Figure 3. Chart of temperature and precipitation changes by months in Özalp

Yörede yaklaşık olarak 3 aylık bir kurak dönemin varlığı, bitkisel ve hayvansal üretimi genellikle olumsuz etkilemektedir. Yaz kuraklığı buğday ve arpa gibi tahılların yetiştirilmesini olumlu etkilerken su isteği fazla olan kültür bitkilerini sulama yapmaksızın yetiştirmeyi imkânsız hale getirmektedir. Ayrıca meralardaki otların yaz mevsiminin başlaması ile birlikte sararıp solması, meralarda otlatılan hayvanların et ve süt verimini düşürmektedir.

Araştırma sahasının yakın çevresinde yer alan çeşitli mağaralar, vadiler ve yüksek yaylalarda çok eski dönemlerde yapıldı̆̆ı tespit edilen bazı resimler bulunmuştur. Dorutay ovasına yakın konumda yer alan Gürpınar ilçesine bağlı Yedisalkım (Put) Köyü yakınındaki bir vadideki 60-70 mağaranın dördünde kırmızı ve kahverengi boya ile yapıımış çeşitli resimler bulunmaktadır. Bu resimleri inceleyen uzmanlar bazı resimlerin oldukça eski olup 8000 ile 15000 yıl kadar önceye ait olduklarını ileri sürmüşlerdir (Erzen, 1992). Söz konusu rakamlar, bahsedilen mağara resimlerinin Türkiye ve Avrupa'da tespit edilen diğer mağara resimlerine göre daha eski topluluklara ait olduklarını göstermektedir.

Sahanın yakın çevresinde yer alan Çatak ilçesi sınırlarındaki Tirişan (Tirşin) ve Gevaruk yaylalarında, kayalar üzerine çizilmiş binlerce resim tespit edilmiştir. Bu resimlerin, doğuda Azerbaycan'da, güneyde ise Filistin'de tespit edilen kaya resimleriyle çok yakın bir benzerlik göstermesi ilginçtir. Bahsedilen resim- lerin günümüzden yaklaşık 1000 ile 6000 yıl öncesine ait oldukları tespit edilmiştir (Alper, 2001). Şüphesiz elde edilen bu deliller, inceleme alanı ve yakın çevresinde yerleşme tarihinin çok eski olduğu anlamına gelmektedir.

Araştırma sahasında bilinen tarihi çok eski olan bir yerleşme bulunmamaktadır. Ancak sahanın yakın çevresinde yer alan Saray kasabasının yerleşme tarihi eski dönemlere dayanmaktadır. Saray kasabasının ilk olarak M.S. VI. yüzyılın başlarında Sasaniler tarafindan Bizans'a karşı savunma amaçlı bir kale olarak kurulduğu kabul edilmektedir (Balbal, 2011). Ancak daha öncede anlatıldığı gibi Van çevresinde yerleşme tarihinin günümüzden 7000 ile 15000 yıl öncesine kadar gittiği tahmin edilmektedir. Dolayısıyla araştırma sahasında da yerleşme tarihinin oldukça eskilere dayandığı söylenebilir.

Araştırma sahasında başlıca ekonomik faaliyetler ziraat ve hayvancılıktır. Yörede yer alan okul, sağlık ocağı, cami ve karakollarda görev yapanlar dışında çalışan nüfusun neredeyse tamamı tarım sektöründe istihdam edilmektedir. Yörede önemli bir şehrin olmaması hizmet sektöründeki istihdamın sınırlı olmasına neden olmuştur. Ayrıca araştırma sahasında önemli bir imalat tesisinin bulunmaması, sanayi sektöründe istihdamın sağlanamamasına neden olmuştur.

\subsection{Nüfus Gelişimi}

1935 yılı nüfus sayımına göre Dorutay Ovası ve yakın çevresindeki köylerin toplam nüfusu 4353 kişiden oluşmaktaydı. Belirtilen tarihte Damlacık ve Aşağıkoçkıran dışında inceleme alanında kalan diğer 20 kırsal yerleşmenin köy tüzel kişiliğine sahip olduğu anlaşılmaktadır. 1960 yılında araştırma sahasının nüfusu 7811'e çıkmıştır. 1960 yılında 1935'ten farklı olarak Aşağıkoçkıran Köyü'nün de köy tüzel kişiliği elde ettiği anlaşılmaktadır. Sahanın nüfusu 1935-1960 devresinde 3458 kişi artmıştır. Diğer bir ifade ile yöre nüfusu 25 yılda her yıl \% 3,2 oranında artmıştır.

Dorutay Ovası ve yakın çevresinde 1960-2000 döneminde nüfus 18955 artarak 7811'den 26766'ya çıkmıştır (Tablo 2). 2000 yılında Damlacık'ın da köy tüzel kişiliğine sahip olduğu ve yörede köy tüzel kişiliğine sahip yerleşme sayısının 22'ye çıktı̆ı anlaşılmaktadır. Bu dönemde sahanın nüfusu yılda \% 6,1 oranında artmıştır. 1950'den sonra ülke genelinde olduğu gibi araştırma sahasında da nüfus artış hızının yükseldiği anlaşılmaktadır. Bu dönemde artş̧ hızının oldukça yüksek olmasında dışarıya yönelik göçlerin henüz başlamamış olması da önemli bir etkendir.

Dorutay ovası ve yakın çevresinde yer alan köy yerleşmelerinde günümüzde 29939 kişilik bir nüfus bulunmaktadır. İnceleme alanının nüfusu 2000 yılında ise 26766 kişiden oluşmaktaydı. Bu veriler sahanın nüfusunun son 15 yılda yaklaşık 3171 kişi arttı̆ını göstermektedir. Diğer bir ifade ile sahanın nüfusu son 15 yılda her yı \% 0,8 oranında artmıştır (Tablo 2). Oysa 2015 yılı verilerine göre Özalp'ta doğal artış hızı \% 2,59'dur (Tablo 3). Yani yörede yıllık gerçek nüfus artış hızı ile doğal artı̧ hızı arasındaki fark \% 1,79'dur. Şüphesiz nüfusun yıllık gerçek artş hızının doğal artş̧tan az olmasının yegâne nedeni, yöreden dışarıya yönelik göçlerdir. Geçim kaynaklarının sınırlı olduğu, sosyal yapıdan dolayı zaman zaman kırsal yerleşmelerde yaşayan aileler arasında problemlerin yaşandığı yöreden dışarıya yönelik göçler devam etmektedir. 
Tablo 2. Dorutay Ovası ve yakın çevresindeki köylerin sayım dönemlerine göre nüfusları ve bu köylerin nüfuslarının son 15 yıldaki değişim Table 2.The population of non-urban settlements in plain Dorutay and immediate surroundings in terms of census periods and change of them in last 15 years.

\begin{tabular}{|c|c|c|c|c|c|c|}
\hline Köyler & $\begin{array}{l}1935 \text { Yill } \\
\text { Nüfusu }\end{array}$ & $\begin{array}{l}1960 \text { Yill } \\
\text { Nüfusu }\end{array}$ & $\begin{array}{l}2000 \text { Yill } \\
\text { Nưfusu }\end{array}$ & $\begin{array}{l}2015 \text { Yill } \\
\text { Nứusu }\end{array}$ & $\begin{array}{l}2000 \text { ile } 2015 \text { Yillar } \\
\text { Arasinda Artan-Azalan }\end{array}$ & $\begin{array}{c}\text { Yillik Artss-Azalis } \\
\% \text { 'si }\end{array}$ \\
\hline Aksorguç & 348 & 521 & 1623 & 2100 & 477 & 2,0 \\
\hline Asagáıbalqııkı & 301 & 208 & 591 & 544 & -47 & $-0,5$ \\
\hline Aşağıkoçkıran & - & 200 & 823 & 1278 & 455 & 3,7 \\
\hline Aşağttulgalı & 226 & 561 & 1612 & 2303 & 691 & 2,9 \\
\hline Aşağıyorganlı & 64 & 141 & 614 & 708 & 94 & 1,0 \\
\hline Bakışık & 121 & 424 & 1589 & 1798 & 209 & 0,9 \\
\hline çavuşar & 63 & 109 & 445 & 518 & 73 & 1,1 \\
\hline Çubuklu & 447 & 916 & 2744 & 3003 & 259 & 0,6 \\
\hline Damlacık & - & - & 456 & 753 & 297 & 4,3 \\
\hline Dağdeviren & 262 & 452 & 1279 & 1299 & 20 & 0,1 \\
\hline Dorutay & 351 & 557 & 1778 & 1599 & -179 & $-0,7$ \\
\hline Dönerdere & 99 & 232 & 876 & 627 & -249 & $-1,9$ \\
\hline Eğribelen & 157 & 252 & 699 & 660 & -39 & $-0,4$ \\
\hline Günyüzlü & 199 & 261 & 730 & 931 & 201 & 1,8 \\
\hline Oymakı & 172 & 343 & 1180 & 1287 & 107 & 0,6 \\
\hline Sağmalı & 685 & 1145 & 4716 & 4773 & 57 & 0,1 \\
\hline Tekindere & 133 & 265 & 921 & 983 & 62 & 0,5 \\
\hline Yavuzlar & 72 & 85 & 383 & 420 & 37 & 0,6 \\
\hline Yukarbalçıklı & 169 & 281 & 1053 & 1066 & 13 & 0,1 \\
\hline Yukantulgalı & 146 & 360 & 1258 & 1787 & 529 & 2,8 \\
\hline Yukaryorganlı & 109 & 162 & 459 & 252 & -207 & $-3,0$ \\
\hline Yumruklu & 229 & 336 & 937 & 1250 & 313 & 2,2 \\
\hline Toplam & 4353 & 7811 & 26766 & 29939 & 3171 & 0,8 \\
\hline
\end{tabular}

Tablo 3. Özalp İlçesi'nde Kaba Doğum, Kaba Ölüm ve Doğal Artı̧̧ Hızı (2015) Table 3.Crude birth, crude death and natural growth rate in Özalp district (2015)

\begin{tabular}{lc}
\hline Doğum Sayısı & 2033 \\
\hline Ölüm Sayısı & 219 \\
YıI Sonu Nüfus & 70057 \\
Ham Doğum Oranı $(\%)$ & 29,0 \\
Ham Ölüm Oranı $(\%)$ & 3,1 \\
Doğal Artış Hızı $(\%)$ & 25,9 \\
\hline Kaynak: TÜlK &
\end{tabular}

Araştırma sahasının toplam nüfusu son 15 yılda artmıştır. Ancak tablo dikkatli incelendiğinde son 15 yılda sahada yer alan köylerin 17'sinde nüfusun arttğı, buna karşın 5'inde ise nüfusun azaldığı görülmektedir (Tablo 2). Araştırma sahasında doğal nüfus artış hızı Türkiye'deki ortalama değer olan \% 1,35'ten fazla iken göçten dolayı yörenin gerçek yıllık nüfus artış hızı \% 0,8 gibi küçük bir değer almıştır.

Araştırma sahasında yer alan 22 köy tüzel kişiliğinden 20'sinin idari alanında birer yerleşme ünitesi bulunurken 2'sinin idari alanında 2'şer yerleşme ünitesi bulunmaktadır. Bakışık Köyü'nün idari alanında adı geçen köyün dışında Güzeldere Mahallesi bulunurken Aşağıkoçkıran Köyü’nün idari alanında da adı geçen köy ve bu köye bağlı Yukarıkoçkıran Mahallesi bulunmaktadır.

\subsection{Köy Yerleşmeleri}

\subsubsection{Konumlarına göre köyler}

Araştırma sahasında yer alan köyler genellikle Dorutay Ovası'ndaki hafif eğimli ve yüksek sahalar ile bu ovanın çevresinde yer alan dağ ve tepelerin eteklerinde yer almaktadırlar. Çubuklu ve Yavuzlar gibi bazı köy yerleşmeleri ise nispeten yüksek eğimli sahada kurulmuşlardır (Şekil 2).

İlkbahar aylarında kar erimesi ve yağmur nedeniyle akarsuların debilerinin artması ve taşkınların meydana gelmesi (Saraçoğlu, 1989) ovanın en alçak kesimlerinin yerleşim yeri kurmak amacıyla tercih edilmemesine neden olmuştur. Nitekim ovanın merkezi kesimlerine denk gelen ve kuzeybatıda Sağmalı Köyü’nden başlayarak güneydoğuda Bakışık Köyü'ne kadar uzanan bir alanda hiçbir yerleşme bulunmamaktadır (Şekil 2). Yerleşmeler belirtilen alanın etrafinda nispeten yüksek alanlarda bu- lunmaktadır. Ovanın eğimli kesimlerinde kurulan köylerin yer seçiminde tarım olanakları, su ve ulaşım gibi faktörlerin etkili olduğu söylenebilir. Dorutay, Dönerdere, Bakışık, Günyüzlü, Eğribelen, Oymaklı, Aşağıtulgalı ve Sağmalı gibi köyler ovada veya ovadaki hafif engebeli alanlarda kurulan yerleşmelere örnektir (Fotoğraf 2, 3 ve 4)

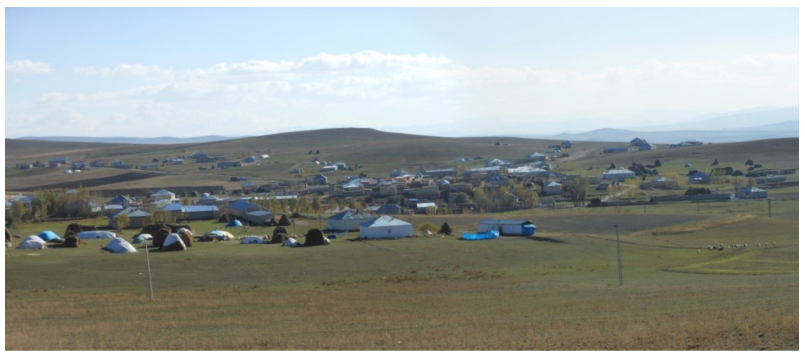

Fotoğraf 2. Eğribelen Köyü.

Photo 2. Eğribelen village.

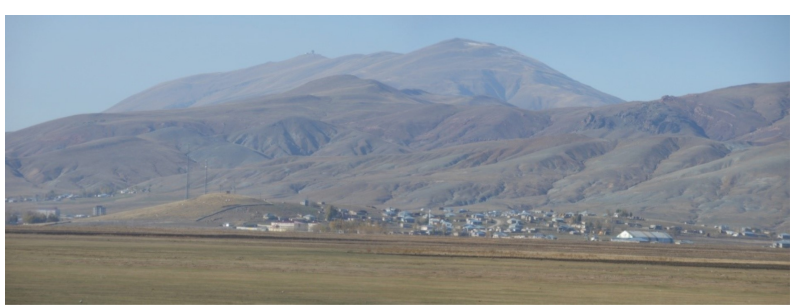

Fotoğraf 3. Sağmalı (Aşağısağmallı) Köyü.

Photo 3. Sağmalı (Aşağısağmallı) village.

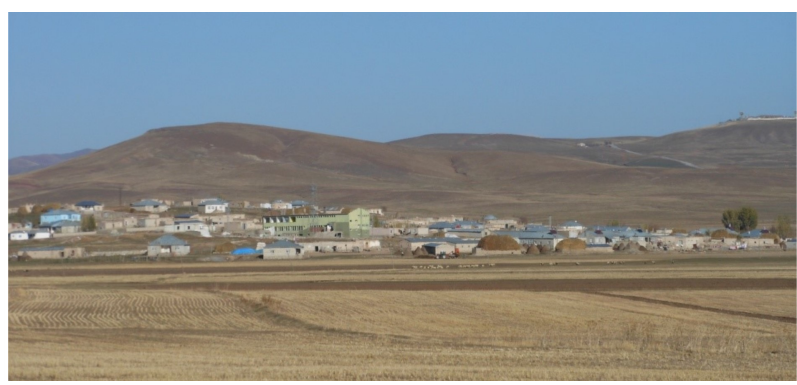

Fotoğraf 4. Oymaklı Köyü.

Photo 4. Oymaklı village.

Inceleme alanında dağ ve tepe etekleri yerleşme sayısının fazla olduğu alanlardır. Buraların yerleşim yeri olarak seçilmesi ile araziden yararlanma arasında bir ilişki olduğu düşünülmektedir. Çünkü bu konumda kurulan köylerde dağlık ve tepelik alanlar mera, düzlükler ise tarla olarak kullanılmaktadır (Doğanay, 2014). Bu yerleşmeler etekte kurulduğu için soğuk kış aylarında ulaşım açısından bir problem yaşanmamaktadır. Aksorguç, Çavuşlar, Yumruklu, Yukarıtulgalı, Damlacık gibi köyler dağ ve tepe eteklerinde kurulan köylere örnektir (Fotoğraf 6, 7 ve 8).

Dorutay Ovası'nın çevresinde nispeten yüksek kesimlerde kurulan Dağdeviren, Çubuklu, Tekindere, Yavuzlar, Aşağıkoçkıran, Aşağıbalçıklı, Aşağıyorganlı gibi köylerde ise çevredeki dağlık alanlar mera hayvancılığını olumlu etkilemektedir. İklim koşullarının daha sert olduğu bu alanlarda dışarıya yönelik göçlerin nispeten fazla olduğu ve bazı köylerin nüfus miktarının sahadaki ortalama değere göre oldukça düşük olduğu görülmekte$\operatorname{dir}$ (Tablo 2). 


\subsubsection{Yükselti basamağına göre köyler}

Araştırma sahasında yükseltini fazla olması doğal olarak yerleşmelerin kurulduğu yükseltinin alt sınırının da 2000 m.nin üzerinde olmasına neden olmuştur. Sahada köy yerleşmeleri 2000-2250 m.ler arasında yer almaktadır.

Dorutay ovası ve yakın çevresinde bulunan 22 köy yerleşmesinden 8'i 2000-2100 m. yükselti basamağında yer almaktadır. Diğer bir ifade ile sahadaki köylerin \% 36,4'ü bu yükselti basamağında yer almaktadır (Tablo 4). Araştırma sahasının en alçak kesimini oluşturan bu yükselti basamağındaki köyler, Dorutay ovasında veya ovanın içinde yer alan alçak tepelerin üzerinde veya eteğinde yer almaktadırlar (Fotoğraf 5, 6, 7).

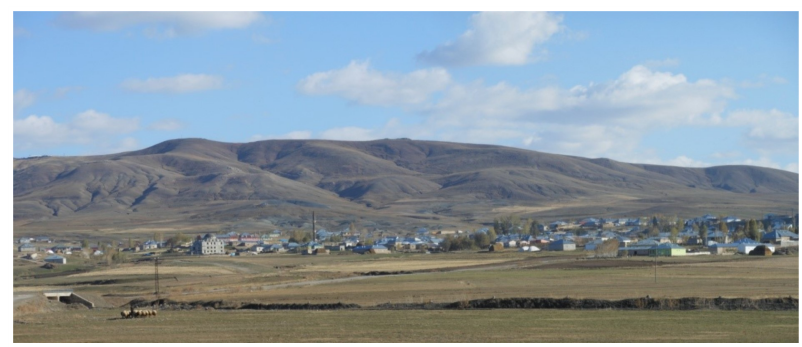

Fotoğraf 5. Bakışık Köyü.

Photo 5. Bakışık village.

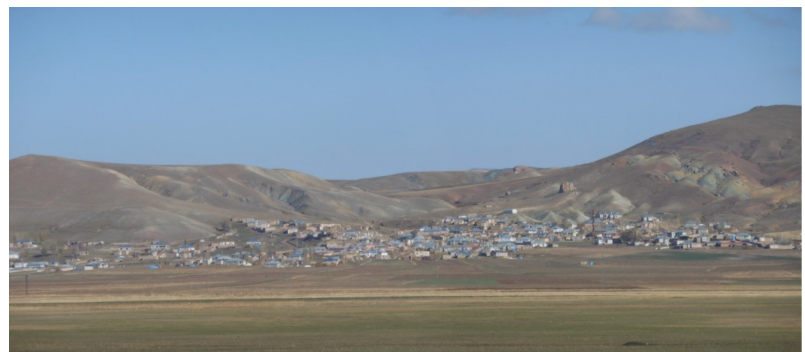

Fotoğraf 6. Yumruklu Köyü.

Photo 6. Yumruklu village.

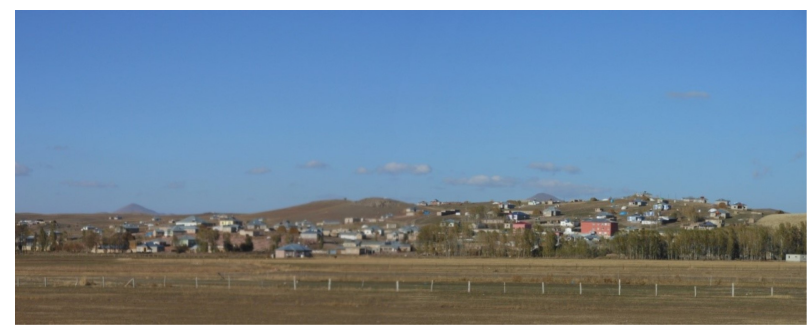

Fotoğraf 7. Aşağıtulgalı Köyü.

Photo 7. Aşağıtulgalı village.

Çalışma sahasında 12 köy yerleşmesi ise 2101-2200 m. irtifa kademesinde yer alır. Diğer bir ifade ile sahadaki köylerin \% 54,5'i belirtilen irtifa kademesinde yer almaktadır (Tablo 4). Çaışma sahasında yer alan köylerin yarıdan fazlasının bulunduğu bu irtifa kademesindeki köyler daha ziyade Dorutay ovasını çevreleyen dağ ve tepelerin eteğinde veya üzerinde yer alır (Fotoğraf 6).

\subsubsection{Yerleşme dokularına göre köyler}

Araştırma sahasında yer alan köylerin tamamı toplu dokulu küme köyü formundadır (Fotoğraf 5-6-7-8). Ancak son yıllarda bazı ailelerin köyün nüvesinin biraz uzağında yer alan tarlalar içinde yeni konut ve eklentileri yapmaları, bu dokunun bozulmasına neden olmaktadır (Fotoğraf 9-10).

Belirtilen etken, kırsal nüfusun daha modern konutlarda yaşamasına imkân vermektedir. Ancak tarım arazilerinin konut yapmak amacıyla gelişigüzel bir şekilde kullanılması uzun vadede hem arazinin amaç dışı kullanımını yaygınlaştıracak, hem de eğitim, sağlık, ulaşım ve iletişim gibi bazı hizmetlerin sağlanmasını güçleştirecektir.

Tablo 4. Dorutay Ovası ve yakın çevresinde yer alan köylerin yükselti kademelerine göre dağılımı

Table 4. The distribution of the village settlements in plain dorutay and immediate surroundings according to elevation steps.

\begin{tabular}{|c|c|c|c|}
\hline Yükselti Basamağı & Köy Sayısı & Oran $(\%)$ & Köyler \\
\hline $2000-2100$ & 8 & 36,4 & $\begin{array}{l}\text { Aksorguç, Dorutay, Eğribelen, Günyüzlü Oymaklı, } \\
\text { Sağmallı, Yumruklu, Dönerdere, }\end{array}$ \\
\hline \multirow[t]{2}{*}{$2101-2200$} & & & A.Balı̧ıklı, A.Koçkıran, A.Tulgalı, A. Yorganlı, Bakışık, \\
\hline & 12 & 54,5 & $\begin{array}{l}\text { Çavuşlar, Çubuklu, Damlacık, Dağdeviren, Y. } \\
\text { Balçıkl, Y. Yorganlı, Tekindere }\end{array}$ \\
\hline $2201+$ & 2 & 9,1 & Yavuzlar, Y. Tulgalı \\
\hline Toplam & 22 & 100 & - \\
\hline
\end{tabular}

Kaynak: Topoğrafya haritaları ve yerinde yapılan tespitler.

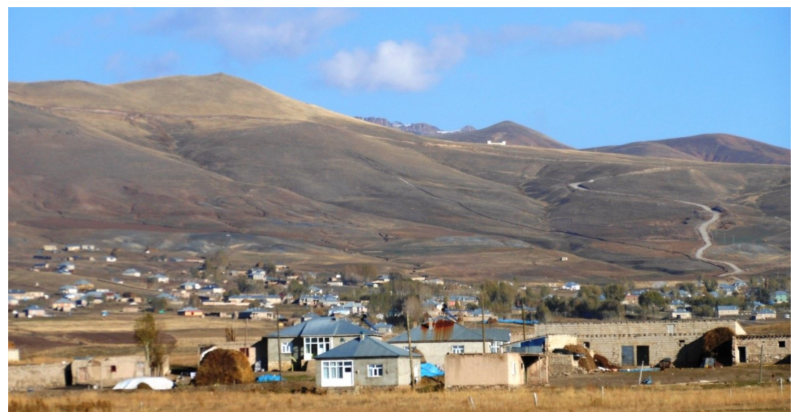

Fotoğraf 8. Yukarıtulgalı Köyü.

Photo 8. Yukarıtulgalı village.

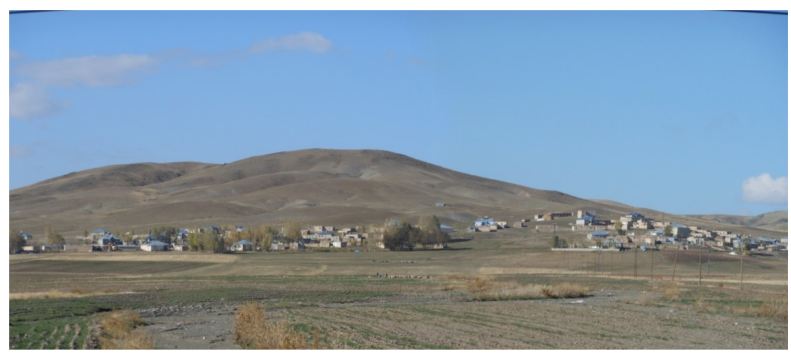

Fotoğraf 9. Çavuşlar Köyü’nün nüvesi.

Photo 9. The core of Çavuşlar village.

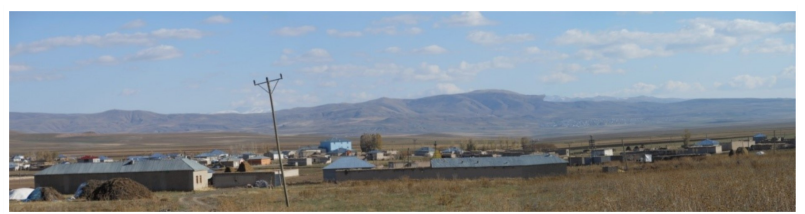

Fotoğraf 10. Çavuşlar Köyü'nde ilk yerleşim alanının uzağında yapılmış yeni konut ve eklentileri.

Photo 10. The newly built housing and plug-ins far from the first settlement in Çavuşlar village.

\subsubsection{Yer adlarına göre köyler}

Yer adları, yerleşmenin tarihi gelişimi ve coğrafi çevrenin geçmişteki durumu hakkında bilgi veren kaynaklar olmaları açııın- 
dan incelenmesi son derece önemli olan bir konudur (Göney, 1975). Eski kültür yörelerinin zamanımıza kadar gelen görünümlerini ve oluşum tarzlarındaki zindeliği tanımak, açıklamak ve yorumlamak; bununla da yöre tarihi ve eski yöreler için yapılan çok boyutlu araştırmalar bir belge olarak önem kazanır (Karaboran, 1984). Tümertekin'in de belirttiği gibi yerel adlar kültürel coğrafi görünümdeki en önemli özelliklerden birisidir (Tümertekin ve Özgüç, 2011). Bu çalışmada detaylı bir toponomik araştırma yapılmamış sadece yerleşme adları üzerinde durulmuştur.

Dorutay Ovası ve yakın çevresindeki köy isimlerinin çoğu 1950 yılında kurulan isim değiştirme komisyonu tarafindan değiştirilmiştir. Belirtilen tarihte araştırma sahasında yer alan 22 köyden 18'nin adı değiştirilmişi 4'ünün adı ise değiştirilmemiştir. Yani Dorutay Ovası ve yakın çevresindeki köylerin \% 81,8'inin ismi 1950 yılından sonra değiştirilmiştir (Tablo 5).

Araştırma sahasında köylerin eski ve yeni isimlerinin fiziki ve beşeri çevreden izler taşıdığı görülmektedir. Eski isimlerden Ahurik, Taşrumi, Tarhani, ve Noşar gibi kelimeleri barındıran isimler, yöredeki düzlüklerin adını almışlardır. Hasantemuran adı aynı zamanda yöredeki küçük bir gölün adıdır. Yine Esbireş Kürtçe Siyah at anlamına gelmektedir. Takurengiz köyü adını yöredeki çok sayıda köyde mensubu olan Takuri boyundan almiştır (Tablo 5).

Araştırma sahasındaki köylerin yeni isimleri de fiziki ve beşeri çevreden izler taşımaktadır. Aşağıbalçıklı, Dorutay, Dönerdere, Tekindere, Yukarıbalçılı gibi köyler isimlerini balçık, ova, dere gibi fiziki coğrafya unsurlarından almıştır. Çavuşlar, Oymaklı, Aşağı ve Yukarıyorganlı ile tulgalı köyleri ise isimlerini çavuş, oymak, yorgan ve tuğla gibi beşeri çevre özelliklerinden almıştır (Tablo 5). Burada tuğlanın yanlışlıkla tulga olarak yazıldığını var saymaktayız.

Yer adlarında yapılan değişiklikler halk nezdinde her zaman kabul görmemektedir (Koday, 2000). Yaptiğımız gözlem ve mülakatlara göre yöre halkının (özellikle de 35-40 yaşın üstünde olanların) eski isimleri bildiklerini ve kullandıklarını, buna karşın yeni isimleri ise genellikle bilmediklerini veya kullanmadıklarını söyleyebiliriz.

Tablo 5. Dorutay Ovası ve yakın çevresinde köy yerleşmelerinin eski ve yeni İsimleri.

Table 5. The old and new names of the villages in plain dorutay and immediate surroundings.

\begin{tabular}{lclc}
\hline Köyün Yeni Adı & Köyün Eski Adı & Köyün Yeni Adı & Köyün Eski Adı \\
\hline Aksorguç & Velicani & Dönerdere & Gıridil \\
Aşağıbalçıkıı & - & Eğribelen & Hasantemuran \\
Aşağıkoçkıran & - & Günyüzlü & Tarhani \\
Aşağıtulgalı & Aşağıhurik & Oymaklı & Takurengiz \\
Aşağıyorganlı & Aşağıgölegeni & Sağmalı & Aşağınoşar \\
Bakışık & Avzerik & Tekindere & Esbireş \\
Çavuşlar & Yadigar & Yavuzlar & Kayseran \\
Çubuklu & - & Yukarıbalçıkı & - \\
Damlacık & Reşan & Yukarıtulgalı & Yukarıahurik \\
Dağdeviren & Kolo & Yukarıyorganlı & Yukarıgölegeni \\
Dorutay & Taşrumi & Yumruklu & Pirmeryem \\
\hline
\end{tabular}

Kaynak: 1960 Yılı Genel Nüfus Sayımı Sonuçları

\subsubsection{Nüfus büyüklüğüne göre köyler}

Araştırma sahasında yer alan 22 köyün idari alanlarında toplam 29939 kişi yaşamaktadır. Bu veri günümüzde yöredeki köylerin idari alanında ortalama 1360 kişinin yaşadığını göstermektedir. Ancak 1360 rakamı ortalama bir değer olup gerçekte yöredeki köylerin nüfusları 252 (Yukarıyorganlı) ile 4773 (Sağmalı) arasında değişmektedir (Tablo 2 ve Şekil 4). 2013 yılına kadar belediye örgütünün de bulunduğu Sağmalı́nın nüfusu yöredeki diğer köylere göre oldukça fazladır (Şekil 4). Ancak Sağmalı'da son yıllarda aileler arasında yaşanan sosyal çatışmalar göçlere ve belirsizliklere neden olmuştur. Bu yerleşmenin nüfusu 2014 yılında 4950 civarında iken göçlerden dolayı 2015 yılında yaklaşık 200 kişi azalmıştır. Yörede nüfusu en fazla olan ikinci köy Çubuklu'dur (Tablo 2).

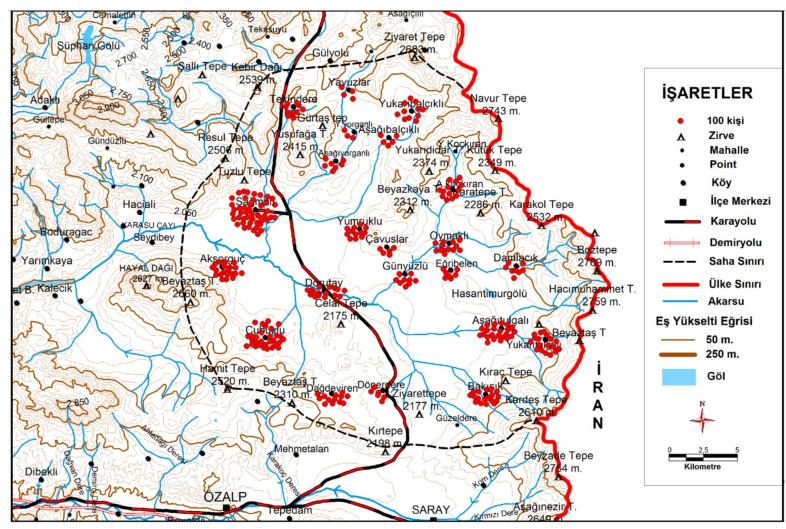

Şekil 4. Dorutay ovası ve yakın çevresinde nüfusun köy yerleşmelerine göre dağılımı haritası (2015).

Figure 4. The map of the population distribution in plain Dorutay and immediate surroundings (2015).

Araştırma sahasında yer alan köylerin nüfuslarının belli aralıklara göre dağılımı incelendiğinde; 2 köyün nüfusunun 500'den az, 8'nin nüfusunun 501-1000 arasında, 5'inin nüfusunun 10011500 arasında, 3'ünün nüfusunun 1501-2000 arasında 4'ünün nüfusunun ise 2001 'den fazla olduğu görülmektedir. Diğer bir ifade ile Dorutay Ovası ve yakın çevresinde yer alan köy idari alanlarının \% 9,1'inde nüfus 500'den az, \% 36,4'ünde nüfus 500-1000 arasında \% 22,7'sinde 1001-1500 arasında, $\% 13,6$ 'sında 1501-2000 arasında, \%18,2'sinde ise 2001'den fazladır (Tablo 2 ve Tablo 6).

Araştırma sahasında nüfus miktarı az olan köyler sayılarına oranla sahanın toplam nüfusunun daha azını oluştururken nüfus miktarı fazla olan köyler ise sayılarına oranla inceleme alanı nüfusunun daha büyük bir kısmını barındırmaktadırlar. Nüfusu 500'den az ve 501-1000 arasında olan köyler inceleme alanındaki köylerin sırasıyla \% 9,1 ve 36,4'ünü oluştururken bu yerleşmelerin araştırma sahasındaki toplam nüfusu içindeki payları sırasıyla \% 2,2 ve 19,2'dir. Nüfusu 1001-1500 arasında değişen köylerin sahanın toplam nüfus içindeki payları ile sayılarının toplam köy sayısı içindeki payının birbirine yakın olduğu söylenebilir. Bu köyler inceleme alanındaki köylerin \% 22,7'sini oluştururken söz konusu yerleşmelerin toplam nüfusu, saha toplam nüfusu içindeki payı biraz daha az olup $\% 20,6$ 'dır. Buna karşın nüfusu 1501-2000 ve 2001'den fazla olan köyler, araştırma sahasındaki köylerin sırasıyla \% 13,6 ve \% 18,2'ini oluştururken bu köylerin nüfusları inceleme alanı nüfusunun \% 17,3 ve \% 40,7'sini oluşturmaktadır (Tablo 6).

Verilerden de anlaşılacağı üzere araştırma sahasında nüfusu 1501 'den fazla olan 7 köy sahadaki toplam nüfusun \% 58'ine sahipken geri kalan 15 köyün nüfusu ise saha nüfusunun \% 42'sini oluşturmaktadır (Tablo 6). Bu veriler araştırma saha- 
sında nüfusun köyler arasında dengeli bir şekilde dağılmadığını göstermektedir. Şüphesiz köy idari alanlarının ve dolayısıyla geçim kaynaklarının farklı olması ve ayrıca yöredeki köylerde göç hızının farklı olması, nüfus miktarlarının farklılaşmasının temel nedenleri olarak gösterilebilir.

Tablo 6. Dorutay ovası ve yakın çevresindeki köylerin nüfus miktarlarının belli aralıklara göre dağılımı (2015).

Table 6. The distribution of the population in a certain range of the village settlements in plain Dorutay and immediate (2015).

\begin{tabular}{lccccc}
\hline Nüfus Aralı̆ı & Yerleşme Sayısı & Oranı (\%) & Nüfus Miktarı & Oranı (\%) & Ort. Nüfus Büyüklüğü \\
\hline 500'den az & 2 & 9,1 & 672 & 2,2 & 336 \\
501-1000 arası & 8 & 36,4 & 5724 & 19,2 & 716 \\
1001-1500 arası & 5 & 22,7 & 6180 & 20,6 & 1236 \\
1501-2000 arası & 3 & 13,6 & 5184 & 17,3 & 1728 \\
2000'den fazla & 4 & 18,2 & 12179 & 40,7 & 3045 \\
Toplam & 22 & 100,0 & 29939 & 100,0 & 1360 \\
\hline
\end{tabular}

\subsubsection{Ekonomik faaliyetlere göre köyler}

Araştırma sahasında yer alan kırsal yerleşmelerde yaşayan halkın temel geçim kaynağı tarım ve hayvancılıktır. Yörede yaptğımız gözlem ve mülakatlara göre tüm yerleşmelerde hem ziraatın hem de hayvancılığın yapıldığını söyleyebiliriz. Ancak illa da bir sınıflandırma yapmak gerekirse ovada yer alan köylerde halkın geçiminde başta gelen ekonomik faaliyet ziraatken daha yüksek kesimlerde kurulan köylerde hayvancılık en önemli ekonomik faaliyet olarak dikkate çekmektedir.

Yörede genel olarak hayvancılık daha önemli bir ekonomik faaliyet olup ziraat hayvancılığı destekler niteliktedir. Dorutay Ovası'nda yapılan hayvancılık ve bitkisel üretim faaliyetlerinin niteliği için Özalp ilcçesi'ne ait bazı verilerin fikir vereceğini düşünmekteyiz. Bu nedenle adı geçen ilçeye ait veriler aşağıda irdelenmiştir.

2014 yılı verilerine göre Özalp İlçesi'nde 152277 dekarlık bir alanda bitkisel üretim gerçekleştirilmiş ve bu alanın \% 72,63'üne tahıl (buğday ve arpa), \% 27,31'ine yem bitkileri (yonca ve korunga) ekilmiştir (Şekil 5). Tahıllar ve yem bitkilerinin dışında Özalp'ta çok sınırlı bir alanda patates ve yağlı tohumların (aspir) ekildiği, ayrıca yine sınırlı bir alanın meyve ağaçlarıyla kaplı olduğu anlaşılmaktadır. Yörede tahıllardan buğdayın, yem bitkilerinden yoncanın daha geniş bir alana ekildiği görülmektedir (Tablo 7). Sahada su kaynaklarının fazla olması özellikle akarsulara yakın düzlüklerin yonca ekimine ayrılmasına imkân vermiştir. Kıraç alanlar ise çoğunlukla buğday ekimine ayrılmaktadır.

Tablo 7. Özalp’ta ekili-dikili arazilerin yararlanma bakımından bölünüşü (2014). Table 7. Cultivated-standing land divisions in terms of benefit in Özalp (2014).

\begin{tabular}{lll}
\hline Yararlanma Şekli & Ekiliş Alanı (da.) & Oranı (\%) \\
\hline Tahıl Tarımı (ekili) & 110611 & 72,63 \\
Yem Bitkileri & 41601 & 27,31 \\
Patates & 40 & 0,03 \\
Yağlı Tohumlar & 10 & 0,0 \\
Meyvelik & 15 & 0,1 \\
Toplam & 152277 & 100 \\
Nadas & 165434 & - \\
Genel Toplam & 317711 & - \\
\hline
\end{tabular}

Kaynak: TÜiK

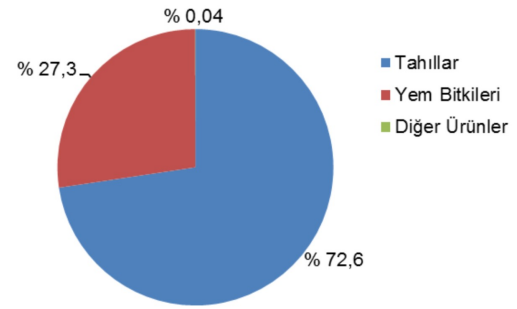

Şekil 5. Özalp’ta ekili-dikili arazinin yararlanma bakımından bölünüşü (2014). Figure 5. Chart of cultivated-standing land divisions in terms of benefit in Özalp (2014).

2014 yılı verilerine göre Özalp’ta hayvan varlığının \% 96,3’ünü koyun oluşturmaktadır. Keçi, sığır ve binek hayvanlarının toplam hayvan varlığı içindeki payları daha az olup sırasıyla \% 0,4 \% 3,2 ve 0,1'dir (Tablo 8). Hayvancılık için gerekli olan yem ve saman, tahıl ve yem bitkilerinin tarımından, kuru ot ise çayırlardan elde edilmektedir.

İnceleme alanında yetiştirilen küçükbaş hayvanların daha ziyade et, süt ve yün verimi düşük yerli ırklardan oluştuğu görülmektedir. Bundan dolayı da hayvancılıktan elde edilen gelirin genellikle az olduğu söylenebilir. Araştırma sahasında hayvan varlığı içindeki oranı az olmakla birlikte melez ve kültür ırkı sığıların yetiştirilmesi, bazı ailelere hayvansal ürün üretiminden daha fazla gelir elde etme imkânı vermektedir.

Yörede hayvan varlığının büyük bir kısmı yerli koyunlardan oluşmaktadır (Fotoğraf 11). Bu durum hayvancılıktan elde edilen gelirin az olmasına neden olmaktadır. Ancak Türkiye gibi canlı hayvan ve et fiyatlarının istikrarsızlık gösterdiği ülkelerde zaman zaman canlı hayvan satımı büyük kazanç sağlayabilmektedir.

Tablo 8. Özalp İlçesi'nde hayvan varlığı verileri (2015).

Table 8. The presence of animals in Özalp district (2015).

\begin{tabular}{lcc}
\hline Hayvan Türü & Sayı & Oran $(\%)$ \\
\hline Koyun (Yerli) & 307800 & 96,3 \\
Kıl Keçisi (Yerli) & 1280 & 0,4 \\
Sığır (Yerli) & 5120 & 1,6 \\
Sığır (Melez) & 3397 & 1,1 \\
Sığır (Kültür) & 1730 & 0,5 \\
Tek Tırnaklılar & 225 & 0,1 \\
Toplam & 319552 & 100 \\
\hline
\end{tabular}

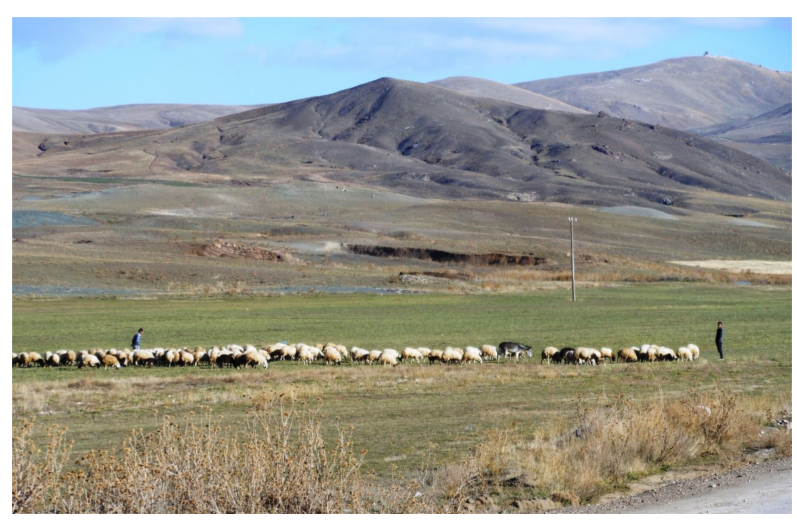

Fotoğraf 11. Bakışık Köyü yakınında otlatılan koyun sürüsü. Photo 11. A flock of sheep near Bakışık village. 
Araştırma sahasının doğu kesiminde yer alan köyler aynı zamanda sınır köyü konumundadırlar. Bu yerleşmelerde yaşayan hane halkının bir kısmı kaçakçılık yapmaktadır. Sınır köylerinde mazot, benzin, pirinç şeker ve çay gibi maddeler kaçak yollarla Türkiye'ye sokulmaktadır (Deniz ve Doğu, 2008). illegal olan bu faaliyeti yapanlar kazanç elde ederken devlet ise kaçakçılıktan dolayı vergi kaybına uğramaktadır. Ayrıca sınırda görevli güvenlik güçlerinin müdahalesi sonucu bazen kaçakçılık yapanların yaralanması ve ölmesi söz konusu olabilmektedir. Dolayısıyla kaçakçılığın ortadan kaldırılması, bunun yerine sınır ticaretinin geliştirilmesi, hem yöre halkı hem de ülkemiz adına daha faydalı sonuçlar doğuracaktır (Yılmaz, 2016b).

İnceleme alanında ikincil ve üçüncül ekonomik faaliyetler gelişmemiştir. Yöredeki köylerde herhangi bir atölye bulunmamaktadır. Bu nedenle inceleme alanında imalat faaliyetlerine dayalı bir geçim yoktur. Yöredeki köylerde bulunan sağlık evi, okul, cami ve karakollarda görev yapan sağlık personeli, öğretmen, imam ve rütbeli askerler ise hizmet sektörü çalışanlarını oluşturmaktadırlar. Sahada yer alan köy okullarında büyüklüklerine göre öğretmen sayısı 3-5 veya 10-15 kişiden oluşmaktadır.

\section{Sonuç ve Öneriler}

Dorutay ovası ve yakın çevresi ülkemizin doğusunda İran sınırında yer alan bir sahadır. Araştırma sahasında günümüzde 22 köy ve 2 mahalle yerleşmesi bulunmakta ve bu yerleşmelerde yaklaşık 30000 kişilik bir nüfus yaşamaktadır.

Araştırma sahasında yaşayan halkın geçimi ziraat ve hayvancılığa dayanmaktadır. Ancak yörede yetiştirilen hayvan ırkları et, süt ve yün (koyun ve keçi) verimi düşük olan ıklardır. Yine yörede buğday, arpa ve yem bitkilerinin birim alandaki verimi düşüktür. Bu nedenle yöre halkı geçim darlığı çekmektedir. Geçim darlığına bağlı olarak yöreden dışarıya yönelik göçler devam etmektedir. Bunun en büyük kanıt günümüzde yörede yıllık doğal nüfus artış hızının \% 2,6 civarında olması buna karşın gerçek nüfus artış hızının \% 0,8 civarında olmasıdır. Aradaki farkın temel nedeni göçlerdir. Ayrıca göçten dolayı 2000-2015 döneminde, sahanın toplam nüfusu yaklaşık 3000 artarken 22 köyden 5'inin nüfusu azalmıştır. Bu durumun nedeni olarak bazı köylerde göç hızının fazla olması gösterilebilir.

Yöreden dışarıya yönelik göçleri azaltmak için ziraat ve hayvancllıktaki verimi arttırmak gerekmektedir. Bunun için et, süt ve yün verimi daha fazla olan hayvan soylarının yaygınlaştırılması, tarımda verimi daha yüksek olan tohumların kullanılması, toprak bakımının yapılması ve doğal gübre kullanımının yaygınlaştırılması sağlanmalıdır.

Yörede önemli bir hayvan varlığının olmasına karşın Dönerdere Köyü dışında hiçbir yerleşmede mandıranın bulunmaması ilginçtir. Yörede üretilen sütün kırsal hane halkının ekonomisine daha fazla katkı yapması için mandıracılığını geliştirilmesi gerekmektedir. Dönerdere'nin yanı sıra Aşağıtulgalı, Sağmalı, ve Dorutay gibi bazı köylerde de küçük mandıraların kurulması ve diğer köylerden de özellikle ilkbahar ve yaz döneminde süt toplanması, kırsal hana halkına sürdürülebilir bir geçim sağlayacaktır.

Ayrıca yörede potansiyeli olan ancak günümüzde çok sınırlı sayıda hane halkı tarafindan yapılan arıcılığın daha fazla hane halkı tarafindan yapıımaya başlanması ve tatlı su balıkçılığının geliştirilmesi, yöre halkının en azından bir kısmının alternatif geçim kaynaklarına kavuşması anlamına gelmektedir. Şüphesiz yörede bu faaliyetlerin başlaması ve yaygınlaşması için ilçe tarım müdürlükleri başta olmak üzere ilgili kamu kuruluşlarına büyük görevler düşmektedir.

Inceleme alanında iklim koşulları serttir. Yaz kuraklığı 3 ay gibi uzun bir zaman diliminde etkili olmaktadır. Bu nedenle yaz kuraklığının olumsuz etkisini azaltmak için tarımsal sulama olanaklarını ve hayvan sulama göletlerini arttırmak gerekmektedir.

Dorutay ovası ve yakın çevresinde yer alan kırsal yerleşmeler genellikle toplu dokuludur. Ancak bazı yerleşmelerde son yıllarda yapılan konut ve eklentilerinin tarla ve mera alanlarına doğru yayıldığı ve yerleşmenin dokusunun toplu olmaktan çıkthğı görülmektedir. Bu durum uzun vadede bir dizi probleme neden olacaktır. Tarım ve mera alanlarının amaç dışı kullanımı, eğitim, sağlık ve ulaşım hizmetlerinin aksaması bu problemler arasında yer almaktadır. Bu nedenle yasal düzenlemeler yapılarak yukarıda bahsedilen durumun önüne geçilmelidir.

Dorutay ovası ve yakın çevresi bir sınır bölgesidir. Bu alanın belirli bir potansiyeli ve üretimi bulunmaktadır. Yörede fiziki ve beşeri çevre şartlarından kaynaklanan çeşitli problemler de vardır. Bu çalışmada yöredeki üretim, potansiyel ve problemler üzerinde durulmuştur. Ayrıca mevcut problemlerin ortadan kaldırılması için bazı çözüm önerileri sunulmuştur. Çalışmanın yöre insanının hayat standardının yükselmesine, yöredeki üretimin artmasına ve göçün azalmasına katkı sağlamasını temenni etmekteyiz.

\section{Kaynakça}

Alper, C. (2001). Çeşitli Yönleriyle Van, Altan Matbaacılık: İstanbul.

Balbal, M. (2011). Her Yönüyle Tarih ve Doğanın Penceresinden İlçemiz Özalp, Pelin Ofset: Ankara.

Deniz, O. ve Doğu, A.F. (2008). "Türkiye-İran Sınırı: Sınırın Coğrafi Durumu ve Sınır Köylerimizin Sosyo-Ekonomik Yapıları". Doğu Coğrafya Dergisi, 19, 49-72.

Doğanay, H. (2014). Türkiye Beşeri Coğrafyası, Pegem-Akademi Yayıncılık: Ankara.

Erinç, S. (1953). Doğu Anadolu Coğrafyası, İstanbul: İstanbul Üniversitesi Edebiyat Fak. Coğrafya Enstitüsü Yayın no:15.

Erzen, A. (1992). Doğu Anadolu ve Urartular, Ankara: Atatürk Kültür, Dil Tarih Yüksek Kurumu, Türk Tarih Kurumu Yayınları, XX. Dizisi, Sayı:8, Ankara.

Göney, S. (1975). Büyük Menderes Bölgesi. İstanbul: İstanbul Üniversitesi Yayın No:1895, Coğrafya Enstitüsü Yayın No:79.

Karaboran, H. (1984). "Türkiye'de Mevki Adları Üzerine Bir Araştırma”, Türkiye Yer Adları Sempozyumu Bildirileri, 1113 Eylül 1984, Kültür ve Turizm Bakanlığı Milli Folklor Araştırma Dairesi, Yayın No:60, Seminer ve Kongre Bildiriler Dizisi:17,Ankara 1984, 97-147.

Koday, S. (2000). "Trakya'da Köy Adlarında Coğrafyanın Etkisi", 28. Coğrafya Meslek Haftası Bildirileri, 221-253. İstanbul.

Saraçoğlu, H. (1989), Doğu Anadolu Coğrafyası, MEB Yayınları, istanbul.

Saraçoğlu, H. (1990). Bitki Örtüsü Akarsu ve Göller, MEB Yayınları, İstanbul.

Tümertekin, E. ve Ögüç, N. (2011). Beşeri Coğrafya, Çantay Yayınları, İstanbul.

Yılmaz, M. (2014). “Erçek Gölü Havzası'ndaki Köy Yerleşmele- 
ri'nin Coğrafi Özellikleri", Atatürk Üniversitesi Sosyal Bilimler Enstitüsü Dergisi, 18(1), 299-328.

Yılmaz, M. (2016a). Erçek Gölü Havzası'nın Beşeri ve İktisadi Coğrafyası, Lambert-Academic-Publishing, Saarbrücken.

Yılmaz, M. (2016b), “Çaybağı (Kotur) Çayı Havzası'nda (Saray/Van) Coğrafi Çevre Koşulları, Kırsal Yerleşmeler ve Ekonomik Faaliyetler: Sorunlar ve Çözüm Önerileri”, The Journal of Academic Social Science Studies, 45 (Spring III), s.337-359.

internet Adresi

http//www.tuik.gov.tr. (son erişim:03/10/2016) 
